It will maintain and develop a library of papers and maps as well as books on Antarctica. It will provide accommodation for workers engaged in antarctic research. It will promote public interest in polar matters by means of lectures and a museum devoted to antarctic materials and equipment.

The University plans to accommodate the Institute in a major annex to the geology school. This would contain a library in which the map collection would be included, a museum which would serve as a meeting-room, generous storage space and a number of small research rooms.

The basis of the reference collections will naturally be the materials collected by Mawson and members of the expeditions which he led, although valuable collections from other parts of Antarctica have been obtained by exchange with the British Museum and other institutions. At present these are largely housed in the Geology Department of the University. Many periodicals and other books have been segregated in a 'polar' room in the University library, and their number will soon be greatly increased as Lady Mawson has announced that she will present, to the Institute the extraordinarily fine library collected by Sir Douglas.
To mark the inauguration of the Institute a small 'Antarctic Room' has been partitioned from the geological museum. This is mainly occupied by rocks arranged on a regional basis and well documented with maps and geological sections. It also serves to illustrate the achievements of the expeditions of which Mawson was a member or which he led.

The interest created by the inauguration of the Institute has been very wide. Representatives of the Royal Society and the Academy of Science of the U.S.S.R. were present and the Australian Academy of Science was represented by its president. Other institutions which were represented included the Royal Geographical Society, the American Geographical Society, the Argentina Institute of Antarctic Affairs and the Scott Polar Research Institute. Messages of goodwill and congratulations were read. In addition, the Governments of the United Kingdom and New Zealand sent representatives and, from the South Australian Government, two Ministers of the Crown attended. Many men with personal experience of antarctic exploration and research were present. The occasion revealed wide approval of the University's move and paid high tribute to a very great Australian. $\quad$ A. R. Aldermax

\title{
TRAINING IN OCCUPATIONAL HYGIENE
}

$\mathrm{T}$ HE twelfth Conference of the British Occupational Hygiene Society was held in London on April 11. The morning session, with Dr. J. C. Gilson in the chair, dealt with the need for training, and the afternoon, with Dr. L. G. Norman as chairman, covered present and future facilities in universities.

Dr. Gilkon opened the proceedings by contrasting the considerable effort now being put into radiation monitoring with the meagre resources available for checking dust and fumes, which he estimated to be a risk to some 150 times as many people as were exposed to nuclear hazards. The disparity of effort on the job was reflected in training resources, and no university courss in occupational hygiene existed.

The interest of management in working conditions was emphasized by Mr. H. F. Spencer, managing director of Richard Thomas and Baldwins, Ltd., who criticized the term 'occupational hygienist'. Dr. J. M. Rogan, of the National Coal Board, who directs one of the largest epidemiological investigations at present being made in the world, considered that the existing employment of industrial medical officers in large concerns, with specialist laboratory help when required, might be more satisfactory than the appointment of broadly trained occupational hygienists.

Dr. K. P. Whitehead of Imperial Chemical Industries, Ltd., and Dr. P. G. Swann of Esso gave accounts of the ranges of activity of the personnel whose health, as industrial medical officers, they had to rafeguard. The former emphasized the diversity of the chemicals handled. In his firm an industrial hygiene research laboratory studied toxicity and advised on works policy and plant design. He could see little need for the employment of industrial hygienists at factory-level in large, well-organized industries although they might be of considerable benefit to smaller firms.
Dr. Capel's firm employed an industrial hygienist, a graduate in chemistry, who had been trained in the United States. His reports were countersigned by one of the medical staff. It was advantageous for the candidate for such a post to have a degree related to the activities of the firm, or possibly a degree in general science, in which case a six months' course in the principles and practice of industrial hygiene would be sufficient. The parent American company maintained a medical research division which served affiliates all over the world and provided toxicological data on all materials handled.

Mr. H. Collinson, chairman of the Trades Union Congress Social Insurance and Industrial Welfare Committee, concentrated on the problem of the small employer with a back-street factory where conditions were often appalling, although work in the highest tradition of craftsmanship might emanate from it. To some extent this was a matter of educating the employer who was unaware and unco-operative towards suggestions for improving working conditions, but it was unlikely that voluntary action was going to be sufficient. The responsibility for making occupational hygiene available to the whole range of industry rested on the Government. The T.U.C. attached great importance to the pioneer work being done by group health services, such as that at Slough. The Nuffield Foundation had recently placed a quarter of a million pounds at the disposal of the Ministry of Labour for the encouragement of such schemes.

It was important that training should include practical experience in factories, which could only be achieved by the persuasive powers of those planning courses.

Ten years experience in providing an occupational hygiene service for the 200 member firms of the Slough Industrial Health Service was described by Dr. D. Hickish. The firms ranged in size from 2 to 2,000 employees and the backing of the group medical 
service was available. Recently, consultant work outside the group has been undertaken. The func. tion of the occupational hygienist was : $(a)$ to recognize environmental stress affecting health; $(b)$ to evaluate the stress ; (c) to prescribe control measures.

The occupational hygienist needed to have studied elementary physiology, industrial medicine and toxicology. Training in sampling and analysis, including dust, radiation and noise, detailed knowledge of heating, ventilating, air-conditioning and lighting, and a familiarity with statistical methods were desirable. Courses at a technical level, in addition to those for graduates, would be advantageous.

The deputy chief inspector of factories, Miss K. Crundwell, deseribed a recent attempt to catalogue the facilities which at present exist for testing factory air. It was going to be difficult to convince industry of the need for testing to such an extent that they were willing to pay for it. Some employers were anxious to improve their working conditions but others might not take kindly to the suggestion that they should pay, as they might see it, for the evidence on which to hang themselves.

The last speaker in the morning session was Dr. S. G. Fortuin, director of the Philips Medical Services, Eindhoven, Holland. He explained that in every plant they tried to have a full-time medical man, whose services might also be shared by smaller firms in the same town. The checking of environmental conditions was the task of the medical department and there was no place for a more or less independent industrial hygiene department. The physician alone should be responsible for the evaluation of health hazards.

The industrial hygiene laboratory was part of the Medical Service; chemists and engineers were employed in this work and no university programme existed in the Netherlands for training tham in the specific theoretical and practical problems of industrial hygiene; postgraduate courses should be organized for this purpose.

In the discussion which followed the first session it was generally agreed that a need for testing facilities existed, and this involved the training of occupational hygienists to carry out environmental measurements. The cost and method of paying for such services was debated and it seemed unlikely that small firms would be willing, or even able, to carry this individu. ally, although trade associations might offer a way round the difficulty. Another problem was the cost of remedial measures, involving re-design of plant or exhaust equipment, which might be crippling to a small undertaking.
The afternoon session was opened by Dr. L. G. Norman. In a survey of courses related to occupational hygiene which are at present available, Dr. C.H. Wood said that very little was offered in Britain. British employers of occupational hygienists, when questioned, were unanimous in stating that the only training provided was in-service, augmented, occasionally, by short courses given, as a rule, by senior members of the staff.

It was difficult to find out what British teaching institutions gave in the way of special courses, as distinct from the comprehensive type in the United States, since no general list was published; neverthe. less quite a number of subjects could be investigated in this way, lectures on radiation hazards being liberally provided.

Mr. S. A. Roach gave an account of a nine-month course in industrial hygiene engineering which was being planned at the London School of Hygiene and Tropical Medicine and which was to open in October 1961 .

Prof. R. E. Lane, who is responsible for the teaching of occupational hygiene in the University of Man. chester, stated that the current course for industrial medical officers lasted two years but required attendance for only a day and a half a week. The department also appointed research fellows who were post. graduate science candidates for M.Se. or Ph.D. degrees.

Prof. R. C. Browne, who occupies the Nuffield chair of industrial health at the University of Durham, felt that the chemistry graduate was usually the best equipped for the work, followed, in order, by physicist, engineer and doctor, though special risks, such as radiation, clearly affected this. Such graduates were in short supply at present.

During the discussion on the afternoon papers the question of payment for training was raised. Several speakers thought that industry, while willing to send employees on short courses lasting a week or two, might not be prepared to lose their services for a year. The suggestion that Government bursaries might be paid drew the reply that all the students taking a somewhat analogous course in public health engineering had been from overseas for several years past, supported by the World Health Organization or their own Governments ; no Treasury support was available for Britons. Other speakers considered it likely that bursaries would become available from industry.

The conference proceedings will be reported in full in the Annals of Occupational Hygiene.

C. N. Davies

\section{CLOSED CIRCUIT TELEVISION IN THE MEDICAL $\mathrm{SCHOOL}$}

\begin{abstract}
A SYMPOSIUM on the applications of television in medical research and teaching was organized at the London Hospital Medical College during May 10-11 by the Medical Committee of the Scientific Film Association in collaboration with the Association for the Study of Medical Education. Since the 2-hr. demonstration of a land-line colour broadcast by a team from Guy's Hospital in 1957 (Nature, 181, 91, 1958) no collective attempt had been made to evaluate
\end{abstract}

and discuss the potential usefulness of closed-circuit television in medicine. This meeting is therefore a welcome sign that the universities are ready to concede that television need not necessarily be equated with mass entertainment. In fact, the conference was well timed, as many of the seventy senior representatives from British medical schools who participated are concerned with the planning of new buildings and the possible incorporation of elosed-circuit television. 